\title{
Slow Fires Still Burn: Results of a Preservation Assessment of Libraries in L'viv, Ukraine, and Sofia, Bulgaria ${ }^{1}$
}

\author{
Brian J. Baird and Bradley L. Schaffner
}

\begin{abstract}
East Central European libraries face a serious threat of the potential disintegration of the vast majority of Slavic publications printed in the twentieth century. This loss will come as result of the combination of inferior materials used to produce most twentieth-century Slavic publications and inadequate facilities to house these collections. In an effort to gain a better understanding of the condition of Slavic publications, over the past two years, the authors have conducted collection condition surveys and reviewed the preservation operations of three major academic libraries in L'viv, Ukraine, and Sofia, Bulgaria. This paper presents the results of these surveys.
\end{abstract}

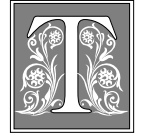

he summer 2002 flooding in East Central Europe, particularly in the Czech Republic, and the damage this natural disaster wrought helped to underscore the preservation challenges facing libraries and archives in this part of the world. Luckily, important volumes in the Czech National Library, located near the Charles Bridge in Prague, were moved to the upper floors before the flood hit the city. ${ }^{2}$ As a result, much of the damage at the National Library was only to the physical plant and its electrical and heating systems, rather than to its collections. ${ }^{3}$ Unfortunately, other libraries in the country were not as fortunate. It is estimated that in the Czech Republic, a "half a million books in the nation's libraries were damaged, along with irreplaceable archival documents and prints."
Dr. Michal Svatos of the Charles University Archive described some of the flood damage: "the Archive of the Czech Academy of Sciences in Troja is completely destroyed. The Archive of Architecture and the Military Archive at Invalidovna suffered great losses; the same applies to the archival materials of the Prague City Archive that were in the depository in Karlin and the archives of the Czech Insurance Company outside of Prague." ${ }^{5}$ Pictures available on the Internet illustrate the extensive damage to these collections. ${ }^{6}$

As tragic as this natural disaster has been in terms of library and archival collections, there is the possibility of an even greater disaster-the potential disintegration of the vast majority of Slavic publications published in the twentieth century. It is not a natural disaster that could

Brian J. Baird is the Preservation Librarian at the University of Kansas Libraries; e-mail: bbaird@ku.edu. Bradley L. Schaffner is the Head of the Libraries Slavic Department and International Programs and the Coordinator of Collection Development at the University of Kansas; e-mail: bschaffn@ku.edu. 
destroy these important materials but, rather, a combination of factors, including the inferior materials (paper and bindings, etc.) used to produce most twentieth-century Slavic publications combined with inadequate facilities to house these collections, that could result in the wholesale loss of the published Slavic cultural record of the past century.

Over the past two years, the authors have conducted collection condition surveys and reviewed the preservation operations of three major academic libraries in L'viv, Ukraine, and Sofia, Bulgaria. The libraries surveyed were the L'viv National University Library and the V. Stefanyk Scientific Library of the National Academy of Sciences of Ukraine, and the Bulgarian National Library. This research was performed as part of a larger project that is attempting to document, in a thoughtful and consistent manner, the condition of Slavic publications throughout the region and in major collections held abroad. The findings from this portion of the research are added to the work that the authors have already carried out on the condition of Slavic materials in the United States. The results of their earlier work have been reported in the article "Into the Dustbin of History?"7 A detailed description of the evaluation questionnaire and procedures developed and used for this survey is located in the article "Findings from the Condition Surveys Conducted by the University of Kansas Libraries." ${ }^{8}$ One of the great obstacles to the preservation of Slavic materials is the fact that most condition evaluations of these publications are based on anecdotal reports and speculation, which are accurate in the fact that most twentieth-century Slavic publications were produced on poor-quality materials. Beyond this however, we really do not fully understand the scope and extent of the preservation challenge that we face in preserving these materials. The overall goal of this research project is to provide a truer picture of the current condition of Slavic materials based on an organized examination of their actual condition. Such research will provide us with a much better under- standing of the task we face in preserving the Slavic printed heritage.

This article first provides an overview of the three libraries visited, along with a short description of the preservation operations at the institutions in an effort to provide the reader with a basic understanding of the preservation capabilities of each organization. It then discusses the results of the collection condition surveys conducted at each library. The findings of this work are rather surprising and go against the long-accepted view that incountry Slavic publications are in poor condition and the quality of facilities used to house these materials are inadequate.

\section{The Bulgarian National Library ${ }^{9}$}

Located between Romania and Turkey and bordering the Black Sea, Bulgaria is a large country of almost 43,000 square miles with a highly literate population $(98 \%)$ of roughly eight million people. The annual per capita income is approximately $\$ 6,200$. Since 1990, when the Communist government collapsed, the people of Bulgaria have strived to develop a democratic form of government and social institutions. ${ }^{10}$

With more than two million volumes and seven million documents, the Bulgarian National Library is the largest library in the country. Interestingly, the three largest libraries in Bulgaria are all located within the same neighborhood of Sofia. World War II witnessed the destruction of the National Library building along with many of its collections. Undeterred by this destruction, the Bulgarian government moved the library to its present location in the mid-1950s.

Since the collapse of communist rule in Bulgaria, government support for social institutions such as libraries has been insufficient to meet the needs of these organizations. Therefore, libraries are constantly struggling to meet their financial obligations to pay staff and to develop and preserve collections.

In 1994, Sonja K. Jordan visited Bulgaria and prepared a thorough report on libraries in that country and the preservation concerns they faced. ${ }^{11}$ This report presents 
a good review of the conditions of libraries in Bulgaria in the mid-1990s and provides an interesting comparison to the conditions the authors found on their visit in 2002. In 1994, Bulgaria had been free from Soviet influence for only five years. At the time, the Parliament was divided, and there was no support for the president and his government. Consequently, progress in establishing social and democratic institutions was slow and often unproductive. As a result, libraries received no clear government support in terms of finance or legislation, greatly inhibiting their ability to fulfill their missions. ${ }^{12}$

At present, libraries in Bulgaria continue to experience difficult times, but despite financial challenges, there is optimism among library professionals. Over the past few years, library leaders have successfully introduced fund-raising programs for their institutions. Formerly, tax laws frustrated these efforts, but now about 20 percent of library funds come from donations. ${ }^{13}$ In addition, The Open Society Foundation has provided critical financial support to libraries in the country. ${ }^{14}$

Established in 1990 by George Soros, The Open Society Foundation has actively supported the development of democratic institutions in countries in Eastern Central Europe and the former Soviet Union. As part of this effort, the foundation provides financial support to libraries in the region so that they can continue to operate while the governments and societies make the transition to democracy. ${ }^{15}$

\section{Preservation Efforts in the National Library}

Staff from the National Library played a leading role in the creation of a countrywide library preservation program in 1997. The initial observations and goals of this program are reported in National Program for the Preservation of Library Collections. ${ }^{16}$ As part of the effort to establish this program, Reny Marcheva, head of the Conservation and Restauration Laboratory at the National Library, traveled to Andover, Massachusetts, to study paper conservation at the Northeast Document
Conservation Center (NEDCC). ${ }^{17}$ At this time, the National Library also began developing professional contacts with library preservation specialists in England and Germany in an effort to further the preservation program.

Although the Bulgarian preservation program began in 1997, there is a long history of conservation efforts at the National Library. The library set up the Conservation and Restauration Laboratory in 1960. Through the years, the laboratory has been home to several talented conservators and bookbinders who have developed innovative preservation and conservation techniques. Printing did not flourish in Bulgaria until after its independence from the Ottoman Empire in the late 1870s, so the country has a very rich history of manuscript production. Consequently, many manuscripts are in need of treatment. In an effort to address this need, Stella Alkalai developed a leaf-casting machine in 1965 and continued to modify and improve it. A second model of her machine remained in use at the National Library through the 1980s. As a result, many manuscripts in the collection have been skillfully treated using leaf-casting techniques.

The leaf-casting performed at the National Library demonstrates excellent workmanship. The fills are consistent and well made. However, pulp used in these restoration efforts was acidic in natureneutral at best. At present, there are no serious signs of deterioration, but the fills have started to yellow slightly, especially the older treatments. Therefore, these fills do represent a preservation concern for the future, but these problems can easily be addressed with deacidification and proper storage, and the leaf-casting efforts preserved hundreds of important manuscripts that were badly fragmented and might otherwise have been lost without this treatment.

The National Library has benefited from the work of experienced and talented bookbinders over the years. The library utilized an apprenticeship arrangement to train employees in the art of bookbinding and other conservation practices. 
However, the last knowledgeable binder at the National Library refused to share his knowledge and skills with a successor, so for nearly twenty years, the library languished without the skills of a talented binder. Consequently, many treated manuscript text blocks are in need of binding.

At present, the National Library has recovered from this loss and has an experienced and talented binder on staff who performs consistent work. Unfortunately, she has been unable to obtain additional training that would allow her to develop her skills to the next level. She focuses her efforts primarily on twentieth-century materials similar to collections conservation efforts in the United States. Based on her skills and experience, it would not take much training to raise her to the next level so that she could function as a highlevel conservation technician.

Except for the binder, the majority of the staff in the Conservation and Restauration Laboratory spend their time on paper-related conservation. The papermending technicians are talented. They primarily wash documents and text blocks, and perform mends with Japanese paper and paste or heat set tissue they make in house with lens tissue and an adhesive they learned to make in Germany several years before. They use this heat set tissue primarily to strengthen embrittled paper, often lamenting entire brittle books. They also produce various types of portfolio enclosures and phase box-type enclosures.

The National Library has had a long tradition of binding materials for its general collections as well and still operates an inhouse bindery to process all serials and many paperback monographs. The bindery staff is incredibly productive and capable but lack adequate supplies to produce high-quality bindings. The department serves as a strong preservation resource that the National Library could expand upon. With additional training, the bindery staff could learn book repair and paper mending, and make boxes for damaged materials in the general collections.

\section{Preservation Efforts in the L'viv National University Library and the V. Stefanyk Scientific Library of the National Academy of Sciences of Ukraine $^{18}$}

Just over ten years have passed since Ukraine declared its independence from the crumbling Soviet Union. The decade has not been easy for the Ukrainian people as they strive to create a democratic state, a free-market economy, and a civil society. As in Bulgaria, this transition period has been extremely difficult for libraries and librarians who now have far less financial support from the government for collections and general library operations than during the Soviet period.

The authors had the opportunity to spend May and part of June 2001 in L'viv visiting the preservation operations and conducting collection condition surveys at the L'viv National University Library and the V. Stefanyk Scientific Library of the National Academy of Sciences of Ukraine. ${ }^{19,20}$ Both libraries are major research institutions with the National University Library holding approximately three million volumes and the Library of the Academy of Science owning about seven million volumes. The University of Kansas (KU) Center for Russian and East European Studies sent the authors to L'viv as part of the U.S. State Department's Newly Independent States College and University Partnership Program grant that was awarded to KU and L'viv National University. ${ }^{21}$ This partnership program funded faculty exchanges between K.U. and L'viv National University for three years. ${ }^{22}$

Ukraine is located between Russia, Poland, and the Black Sea. As the second largest country in Europe, it is slightly smaller than the state of Texas with a highly literate population of almost 49 million people. In 2000, the estimated per capita annual average income was $\$ 3,850$ per year, with more than half the population living below the poverty line. Ukraine declared its independence from the Soviet Union on August 24, 1991. Although more than a decade has passed 
since its independence, the country is still struggling to create a truly democratic form of government. ${ }^{23}$

One of the authors first visited Ukrainian libraries in 1995. At this time, he noted that for libraries, "budgets for acquisitions and daily operations are insufficient and there is little money for capital improvements and systems modernization. In fact, several librarians mentioned that administrators are often forced to decide whether they should use their library's limited resources for acquisitions or to pay employees." ${ }^{24}$ The elimination of Soviet-era government "perks" for libraries, including free postal privileges and reliable deposit copy laws, exacerbated the poor financial situation in the newly independent state.

It appears that the financial situation is slowly improving. The government is drafting new deposit laws to ensure that appropriate libraries will obtain copies of Ukrainian publications gratis. Ukrainian librarians no longer complain, publicly at least, that they are not getting paid for months on end. Unfortunately, salaries for library staff are unremittingly low. All of the librarians interviewed last spring also mentioned that a limited amount of money was now available for the acquisition of a few new publications. Yet, financial resources available to fund the operation of libraries continue to be insufficient to meet the needs of the institutions.

Regardless of the financial situation, enhancements of library services are being instituted. Both the L'viv National University Library and the V. Stefanyk Scientific Library of the National Academy of Sciences of Ukraine are using "smart cards" to control access into the library and to monitor a patron's use of library materials. In the past, patrons had to have a passbook, similar to a passport, to enter a library. Security at libraries was labor intensive, with guards checking everyone who entered and left the building. Now, libraries in L'viv have similar security devices that one would see in most research libraries in the United States. In addition to smart cards, the libraries are working to create online catalogs and to provide access to additional electronic resources, things most users in the U.S. take for granted. As with Bulgaria, limited financial resources are hindering progress. However, librarians are determined and progress is being made despite great difficulties.

Upgrading the physical plant appears to be the biggest challenge facing many libraries in Ukraine. In the realm of facilities, libraries in L'viv are making slow improvements. For example, the main building of the L'viv National University Library has undergone limited renovation, but much work remains to be done. Most important, the roof over the main section of the building that houses the stacks is badly in need of repair. There has been a long-standing problem of water leaking through the skylights that provide natural illumination for the stacks. This, of course, damages the books, many of which were published in the eighteenth and nineteenth centuries. The university and government acknowledge the problem and, as resources become available, they are working to solve it.

Ironically, additional financial resources for construction also could have a negative impact on collections. New buildings and improved heating systems could adversely affect the condition of publications housed in the libraries. About twenty years ago, the L'viv National University Library constructed a building to house some technical service operations and to provide additional stack space. The building has a modern heating system that is, unfortunately, not able to optimally regulate the climate of the building. Because of the fluctuations in temperature, hot and dry in the winter and humid and hot in the summer, the publications in this building are becoming brittle much more quickly than books stored in the main building-an old building with thick stone walls. This design, particularly in the stack areas, results in fairly stable climate conditions. Both temperature and humidity remain reasonably constant throughout the year. As a result, the books do not become brittle as quickly as in the new building. Although the climate in the old building is conducive to 
the preservation of printed material, it is often uncomfortable for the library's employees and patrons. Installing new heating systems in the old building may make it more pleasant for the human occupants but will negatively impact the collections housed in the building. At present, the temperature in the old building remains at about 55 degrees Fahrenheit. Raising the temperature to 70 degrees Fahrenheit will hasten the deterioration of books and reduce the usable life of the collections by more than half.

Both libraries utilize large old churches confiscated by the Soviet government and given to the organizations to use as remote storage facilities. The Ukrainian government is in the process of returning these buildings to their rightful owners. Although this is the correct and just action to take, it will place additional financial hardships on the libraries now searching for new storage facilities. Like the old main building of the L'viv National University Library, these churches provide environmentally advantageous conditions for the storage and preservation of materials. The temperature and humidity in these buildings remain fairly constant throughout the year. If new buildings are constructed, expensive HVAC systems will need to be installed to match the preservation capabilities of the current buildings. Of course, the biggest challenge will be finding the funds to purchase or upgrade appropriate buildings for the libraries.

The V. Stefanyk Scientific Library has a well-developed conservation program. The program has been operating for nearly fifteen years, even during the difficult financial times of the early post-Soviet period. It employs more than a dozen people, including two paper conservators and a bookbinder. The professional staff receive their training by attending workshops in Europe.

The paper conservators and bookbinders are talented and knowledgeable craftspeople. One of their greatest challenges is obtaining appropriate preservation supplies. Perhaps even more difficult is securing adequate funding to purchase expensive conservation materials. Luckily, the staff is resourceful and makes good use of local craftsmen to create needed tools and equipment.

\section{Collection Evaluations}

Although the collection evaluations conducted in L'viv and Sofia focused on Slavic publications, the authors did not exclude publications from other countries when they fell into the random sample. Each of the samples included a number of eighteenth- to twentieth-century publications from a variety of foreign countries, primarily Europe. As table 1 illustrates, Slavic materials comprised the majority of the publications surveyed.

\section{Procedures Used to Conduct the Condition Survey}

The collections condition survey entailed evaluating a combined 900 volumes from the two libraries in L'viv, Ukraine, and 451 volumes from the Bulgarian National Library. The survey instrument used was based on the one developed at the KU libraries when evaluating their general collections and Slavic collections. ${ }^{25,26}$ Consistent data-gathering techniques greatly enhance the value of the surveys and allow data gathered from Ukraine and Bulgaria to be easily compared to the data acquired in early surveys.

Data-gathering techniques followed the procedures developed for the KU libraries' general collection survey for determining the number of sample items needed and for randomly selecting the sample volumes. To ensure random sampling from the entire collection, the following formula was used:

\begin{tabular}{|llll|}
\hline \multicolumn{4}{|c|}{ TABLE 1 } \\
Percentage of Slavic Materials
\end{tabular}


$\mathrm{n}=$ Number of shelves in a location $\div$ number of sample items needed

Counting from the left side of the shelf, the survey sampled the fourth volume from every $\mathrm{n}^{\text {th }}$ shelf. If a fourth volume was not on the shelf, the first available volume to the left was selected. If no volumes were on the shelf, the next available shelf holding volumes was sampled. To guarantee that all volumes had an equal chance of being selected, the sampling technique involved counting shelves rather than ranges because many of the stacks have different numbers of shelves per range.

Because there was no expedient way to determine the exact number of shelves in the libraries, rough estimates, based on a quick review of each library's stack area, were used to determine collection size. These estimates were conservative to ensure that at least 400 volumes in each library were surveyed. Survey samples of $400 \mathrm{vol}-$ umes from each library were large enough to allow for the statistical comparison of each institution with the other and with the data previously gathered at KU. Other than the exceptions stated below, the data gathered show that the conditions of the three collections were similar to one another.

Palm Vx handheld computers and HanDBase database software designed for handhelds were used to conduct the survey. ${ }^{27}$ This expedited the data-gathering process by allowing the authors to survey the items in the stacks rather than gathering them to a central location where the data could be entered onto a laptop computer. Using the handhelds was particularly advantageous for some of the stack locations where there were poor lighting, cramped stacks, and no work areas. It is estimated that without the handhelds, the surveying process would have taken at least twice as long.

Not all of the data collected in the original KU survey were relevant for the Slavic project and did not readily apply to Ukraine and Bulgaria. For example, questions about circulation records (because the collections do not circulate), shelving condition (because they are closed-stack collections), and library binding issues (because most of the binding options available in the U.S. are unavailable in Ukraine and Bulgaria) were not germane. Therefore, the survey was modified to collect data that would be of interest to these libraries in helping them further their preservation plans; and to assist in shaping a national preservation agenda for Slavic collections held in the United States. However, modifications to the survey were not so drastic as to inhibit the ability to compare these data to those gathered previously at KU.

\section{Results from the Condition Survey}

Based on previous conditions surveys, visits to other East Central European libraries, and published anecdotal reports, the authors expected to find the collections in a serious state of disrepair. ${ }^{28}$ Therefore, the results of the survey were rather surprising. Overall, the condition of the collections in the libraries surveyed was quiet good, despite the many challenges (storage conditions, financial support, wars, etc.) they have faced throughout the years-challenges that are far beyond anything experienced in U.S. research libraries.

Most of the following tables present data gathered from both the general survey and the Slavic survey at the KU libraries as well as the results of the surveys in L'viv and Sofia. This comparison provides important context from which to interpret the data for Ukraine and Bulgaria.

Perhaps of most significance to the national preservation efforts in Ukraine and Bulgaria is the percentage of embrittled volumes found in the libraries surveyed. Interestingly, the percentages of brittle books were similar to those found for the Slavic collections at the KU libraries. It was anticipated that, given the poor storage conditions, the lack of air-conditioning in the libraries, and the inferior quality of the materials used in publishing Slavic books, the brittle rate would be well over 50 percent. However, as described earlier, many of the collections in Ukraine were stored in old citadels, cathedrals, or other old stone buildings that naturally moderate the environmental conditions of the materials stored 


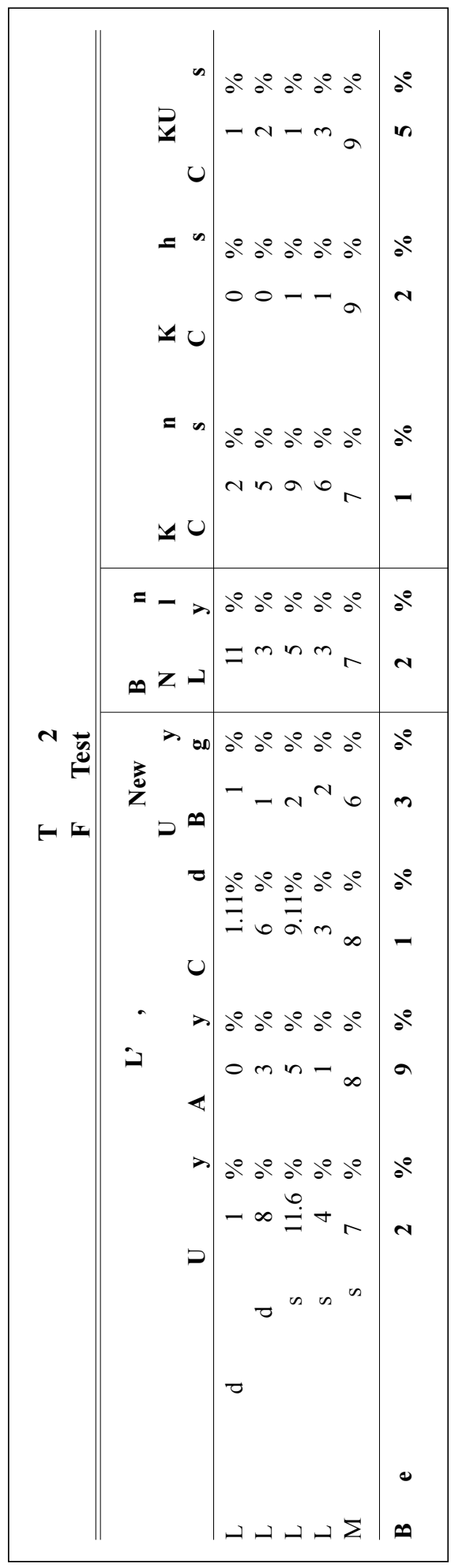

inside. In Bulgaria, the collections were housed in a similar stone library that also naturally moderates the environmental conditions. Environmental observations for these surveys were both anecdotal and scientific. The Academy of Science's conservation department at L'viv holds over ten years of environmental-monitoring data illustrating that many of the buildings maintain very stable conditions with only moderate seasonal fluctuations. The relative humidity remained fairly constant at between 50 and 60 percent. The temperature remains between 50 and 65 degrees Fahrenheit. This has had a very dramatic effect on the percentage of brittle materials in the collections and demonstrates the important role environmental conditions play in preserving collections. As a result of these favorable environmental conditions, the combined L'viv collections have a brittle paper problem similar in magnitude to the Slavic collections at KU. Upon first examination, this may seem logical, but, in reality, KU has a much lower brittle book problem than many other research libraries in the U.S., which often find that as much as 25 percent of their overall collections are brittle. Table 2 shows the results of a fold test testing for brittleness.

As suspected, the survey shows that nearly all of the materials housed in these collections were printed on acidic paper that will eventually become brittle. This result is similar to what was found for the KU Slavic collections. Table 3 shows the survey results with regard to paper acidity.

Nearly one in five books in the combined L'viv collections need preservation treatment of some type. This is nearly three times higher than what was found for the KU Slavic collections. There are several factors that contribute to this greater need for restoration. First and foremost is that there has been very little book repair, conservation treatment, or even binding provided for these collections over the years. In contrast, KU has utilized various binding and repair programs for over fifty years. The cumulative effects of these preservation efforts make a big difference over time. Furthermore, few shelf preparation 
activities have been conducted in the past at the libraries in L'viv. Thin pamphlets are placed in the stacks without support, journal issues are housed unbound for years at a time, and damaged or fragile items receive no special protection or enclosures.

In contrast, the Bulgarian National Library has a long tradition of binding materials before placing them in the stacks and has conducted limited repair work throughout the years. Therefore, even though materials in the Bulgarian National Library receive much higher use than the collections in the L'viv libraries, they are in better condition. This demonstrates the importance of regular binding and repair practices. Table 4 shows a comparison of overall condition of the materials in the L'viv, Bulgarian National Library, and KU libraries.

\section{What Do These Results Mean for the Future?}

As mentioned before, the relative good condition of the collections surveyed in Ukraine and Bulgaria was a pleasant surprise. During the twentieth century, the city of L'viv was the territory of five different nations, each one placing special demands on the libraries regarding what they collected and how materials were processed and cataloged. The two libraries surveyed had both been bombed and plundered during World War II, each losing valuable collections. The Bulgarian National Library also was heavily impacted by the war when the original building was destroyed during a bombing raid, resulting in the current building's construction in the 1950s.

The consequences of these events, combined with the quality of materials used to produce publications in the twentieth century, could have had a devastating effect on the collections. However, the condition of collections is not as bad as one would anticipate and the results of the survey are encouraging. Unfortunately, these collections will not have much of a future without preservation treatments. Currently, there is a window of opportunity in which sig-

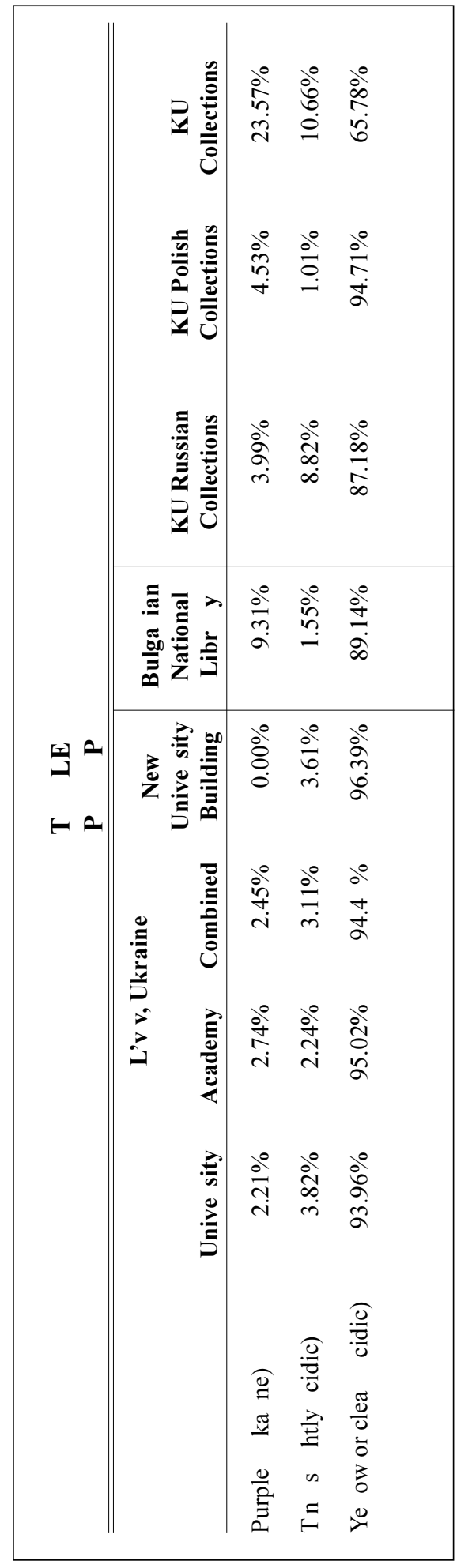




\begin{tabular}{|c|c|c|c|c|c|}
\hline \multicolumn{6}{|c|}{$\begin{array}{c}\text { TABLE } 4 \\
\text { Overall Condition } \\
\end{array}$} \\
\hline & $\begin{array}{c}\text { Combined } \\
\text { L'viv Collections }\end{array}$ & $\begin{array}{c}\text { Bulgarian } \\
\text { National } \\
\text { Library }\end{array}$ & $\begin{array}{c}\text { KU Russian } \\
\text { Collections }\end{array}$ & $\begin{array}{l}\text { KU Polish } \\
\text { Collections }\end{array}$ & $\begin{array}{c}\text { KU } \\
\text { Collections }\end{array}$ \\
\hline $\begin{array}{l}\text { In Good } \\
\text { condition }\end{array}$ & $61.06 \%$ & $69.84 \%$ & $60.71 \%$ & $84.13 \%$ & $83.28 \%$ \\
\hline $\begin{array}{l}\text { Send to } \\
\text { stacks as is } \\
\text { Needs } \\
\text { preservation } \\
\text { treatment }\end{array}$ & $21.68 \%$ & $20.18 \%$ & $34.03 \%$ & $9.82 \%$ & $10.06 \%$ \\
\hline
\end{tabular}

nificant progress can be made to preserve these valuable collections before they are lost forever.

However, the window of opportunity is small. The changing economic conditions in Ukraine and Bulgaria have, for the most part, been favorable for their citizens. But these economic improvements also will result in changes in the libraries surveyed that will greatly threaten the future of their collections. At this time, the collections are housed in old stone buildings that help preserve their holdings. However, many of the collections will have to be moved out of these old historic buildings in the coming years and placed in newer facilities with much poorer environmental conditions. This has already occurred at the L'viv National University Library. The main library is an old stone building with fairly stable environmental conditions. Materials also are housed in a newer building built during the Soviet period. This building has no air-conditioning and poor temperature controls, often resulting in overheating in the winter. Although L'viv has a very moderate climate, the effects of the lessthan-ideal environmental controls can readily been seen. The materials in the new building are very similar in makeup to the collections in the main library. The items housed in the new building have been there for less that thirty years, but, despite that, the brittle rate for the monographs and periodicals in this building is twice as high as the rest of the libraries surveyed in L'viv with a more than 32 percent brittle rate.

Even the materials remaining in old stone buildings will still experience drastic environmental changes in the future as resources become available to improve their heating systems to make the buildings more comfortable for human occupants. The end result will be that within a few years, the vast majority of the collections will rapidly become brittle unless financial resources are made available to install comprehensive climate controls in the buildings to regulate heat and humidity. Given the current state of the economies in Bulgaria and Ukraine, this is unlikely.

It is difficult to overstate the negative impact of these environmental changes on these collections. Hopefully, research projects such as this one will help make the libraries aware of the need for good environmental conditions in order to stem the problem; but in the end, it is clear that some of these improvements will have to be made without adequate resources to fully upgrade the heating system to address the environmental demands of the libraries' collections.

In addition to the environmental changes, the future promises dramatic reconfigurations in how the collections are used. Currently, the stacks are closed, items do not circulate, and bibliographic access to the materials is relatively modest, particularly in the L'viv libraries. However, this will change. Efforts are under way to develop electronic catalogs for the collec- 
tions, and the library staffs are considering a change in circulation policies to better meet the needs of their patrons. These represent important access issues that librarians value, but they will have an impact on the condition of the collections. Both increasing access and allowing materials to circulate will result in damage to thousands of items every year. Currently, there are no facilities available to cope with the influx of damaged materials in the general collections because all conservation efforts are directed toward the libraries' special collections materials. The Bulgarian National Library could provide some binding and book repair services through its current binding procedures, but this would require a significant increase in staffing and supplies, and funding is tight.

In short, the collections are in fair condition at present because they are stored in favorable environments, bibliographic access to the materials is limited, and the materials generally do not circulate. All of these factors will change in the next few years. Any one of these changes would introduce major preservation challenges for the affected library, but the combination of these factors will cause preservation problems to increase exponentially.

\section{What Needs to Be Done}

This leads to the question of what should be done to preserve these collections. To answer that question, one must first step back and look at the needs and resources of both Slavic countries and countries outside the region, particularly the United States. The U.S. has strong preservation and library expertise and experience with the infrastructure and technology to deal with large reformatting projects. The country is wealthy, and funding agencies within the country acknowledge the importance of library preservation and are willing to support such activities. Slavic countries have materials in their collections that would be of great research value to scholars both in the region and beyond. They have a skilled, well-educated workforce that is underemployed, and they are faced with the likelihood that a large portion of their research collections will not survive another generation.

By combining the needs and resources of the Slavic countries and those of the United States, for example, it is possible to create a win-win solution for all parties involved. Librarians from the United States and East Central Europe can work together to select materials of mutual interest to scholars and libraries. Grant funding and library acquisition funds at U.S. institutions could be used to reformat these volumes digitally, allowing individual libraries to secure copies of the text in the format of their choice, whether electronic, paper, or microfilm. The Slavic libraries would provide the labor for putting together lists of titles and making them available to U.S. libraries via an electronic discussion list similar to the SlavCopy program run from the University of Kansas Libraries. ${ }^{29}$ U.S. libraries could sign up for copies of the titles they want. When a volume is copied, grant funds could be used to cover the costs of shipping the book to and from the U.S. and for digitization and reproduction of one copy of the volume for the Slavic library from which the original was contributed.

Thus, U.S. libraries would be able to acquire Slavic materials previously unavailable in this country, East Central European libraries would begin to address some of their preservation concerns, and the costs could be kept low by working cooperatively and taking advantage of lower labor costs in East Central Europe and cost-saving technology from the U.S.

Another important step in preserving these library collections is to utilize the conservation expertise that exists in both countries to further preservation efforts. Both the Bulgarian National Library and the V. Stefanyk Scientific Library in L'viv have trained conservators with moderately well-equipped laboratories. What they lack is funding for additional equipment, supplies, and training. With a modest amount of funding for training and supplies, these libraries could greatly expand their conservation efforts in their own libraries and could begin outreach programs in both countries. 


\section{Conclusion}

The findings of the preservation assessment of collections in the Bulgarian National Library and the L'viv academic libraries do not generally apply to all East European libraries but, rather, are the first step in developing a comprehensive understanding of the challenges faced in preserving these important collections. Many cities in East Central Europe are much more polluted than L'viv or Sofia and have harsher climates. Many library collections are not housed in environmental moderating stone buildings. Further research needs to be done in other Slavic research libraries to fully understand the preservation issues at hand. It is reasonable to speculate that most libraries will have collections in much worse condition than the collections in Sofia and L'viv.

The findings from the current surveys clearly illustrate the absolute importance that environmental conditions play in the long-term preservation of a collection. For years, it has been known that maintaining stable environmental conditions is the single most important factor in preserving a collection. But most of the evidence for this argument was based on lab research and anecdotal information. These survey results now present real-world data that clearly validate the lab research. The lesson to learn here is that libraries should go to extreme lengths to improve and maintain good environmental conditions for their collections. These endeavors are, in the long run, the most cost-effective preservation efforts that can be made.

In addition to confirming the importance of environmental factors on the preservation of publications, the results of this research demonstrate the impor- tance of using a consistent survey tool so that information acquired can be compared to work completed in other locations using the same tool. This allows for the development of a comprehensive view of preservation needs as we work to save important Slavic publications.

The survey instrument developed for this project was based on the one created at the University of Kansas and used successfully many times to evaluate various collections in KU libraries and other U.S. institutions. It was slightly modified for use in Bulgaria and Ukraine. Because of the use of an established survey in a consistent manner, the data reported here can readily be compared to other condition surveys conducted in the past and future, as long as the same procedures are followed. This research is needed in order to develop a baseline of knowledge on the condition of library collections in East Central Europe similar to what we have for research libraries in the United States.

In conclusion, the results of the conditions surveys conducted in L'viv and Sofia clearly indicate that there remains a slight window of opportunity in which we can, by working cooperatively, meet both the acquisition needs of research libraries in the U.S. and address some of the pressing preservation needs of research libraries in East Central Europe. It is important to seize this opportunity by establishing a proactive, cooperative program, such as the one presented above, to begin addressing the access and preservation needs faced by Slavic and U.S. libraries. Only through such cooperation can significant progress be made in addressing the long-term preservation and scholarly research needs for Slavic materials.

\section{Notes}

1. A PowerPoint presentation that includes pictures of the libraries visited and additional data is available online at: http:/ / www2.lib.ku.edu/preservation/SofiaTalkonSurveys.htm.

2. Lydia Rebac, "Spidla Pledges Flood Aid Package," Prague Post, 21 August 2002, 1.

3. Frank Kuznik, “Nation's Cultural Losses Mount in Flood's Wake," Prague Post, 21 August 2002,14 .

4. Ibid., 14 .

5. Posted on the Habsburg discussion list on August 21, 2002. The message is available online at: http://h-net.msu.edu/cgi-bin/logbrowse.pl. 
6. See, for example, The Architectural Archive of the National Technical Museum in Prague online at: http://www.ntm.cz/povodne/fotogalerie/index.htm; The Institute of Archaeology online at http:/ / www.arup.cas.cz/; The Law Faculty of the Charles University, which lost 100,000 volumes, online at: http://www.prf.cuni.cz/mimoradne/fotogalerie.php; The Archive of the Czech Academy of Sciences online at: http://www.archiv.cas.cz/POVOIMG/thumbs.htm.

7. Bradley L. Schaffner and Brian J. Baird, "Into the Dustbin of History? The Evaluation and Preservation of Slavic Materials," College E Research Libraries 60, no. 2 (Mar. 1999): 144-51.

8. Brian J. Baird, Jana Krentz, and Brad Schaffner, "Findings from the Condition Surveys Conducted by the University of Kansas Libraries," College \& Research Libraries 58, no. 2 (Mar. 1997): 115-26.

9. Special thanks to Vania Grashkina, who was instrumental in arranging the authors' visit to the Bulgarian National Library.

10. Current statistical information on Bulgaria can be found at: World Fact Book-Bulgaria on the Web at: http://www.cia.gov/cia/publications/factbook/geos/bu.html\#top; and Transitions Online-the Local Angle. Bulgaria at: http://knowledgenet.tol.cz/look/knowledgeNet/ article .tpl ? IdLanguage $=1 \& I d P u b l i c a t i o n=12 \& N r I s s u e=8 \& N r S e c t i o n=15 \& N r$ Article $=4678$.

11. Sonja K. Jordan, Preservation Activities in Bulgaria: The State of Affairs and Possibilities for Cooperation; Report on a Visit to Bulgaria March 1 to 20, 1994 (Washington, D.C.: The Commission of Preservation and Access, 1995).

12. Ibid., 3-4.

13. Ibid., 4 .

14. Akexander Dimchev, "Bulgarian Libraries in the Global Network Environment," Sofia 2000, "Libraries in the Age of Internet," Sofia, Bulgaria, November 8-11, 2000. Available online from: http://slim.emporia.edu/globenet/sofia/thursmorn2.htm.

15. Borjana Savova, "The Open Society Foundation and the Development of Bulgarian Libraries," Sofia 2000, "Libraries in the Age of Internet," Sofia, Bulgaria, November 8-11, 2000. Available online from: http://slim.emporia.edu/globenet/sofia/thurseve.htm.

16. Ani Gergova, National Program for the Preservation of Library Collections (Sofia: Union of Librarians and Information Services Officers, 1997).

17. For more information about the Northeast Document Conservation Center, visit its Web site at: http://www.nedcc.org.

18. Much of the information on Ukraine was originally presented in Bradley L. Schaffner, "Libraries in Ukraine: A Decade of Independence," International Leads 16, no. 1 (Mar. 2002): 1-2, 8.

19. Available online from: http://www.franko.lviv.ua/library/index.htm.

20. Available online from: http://www.lsl.lviv.ua.

21. Available online from: http://www.ukans.edu/ crees.

22. Information about cooperation between KU and L'viv National University is available online from: http://www.franko.lviv.ua/Intercoop/ku-luwebsite/LU-KUWebsite1.htm.

23. Additional statistical information found in the World Fact Book-Ukraine is available online from: http://www.cia.gov/cia/publications/factbook/geos/up.html.

24. Bradley L. Schaffner, Library Assessment Projects: Ukraine (Washington, D.C.: International Research and Exchanges Board, 1995), 2. This report provides an overview of the situation of libraries in Kyiv and L'viv in the mid-1990s.

25. Baird, Krentz, and Schaffner, "Findings from the Condition Surveys Conducted by the University of Kansas Libraries," 115-26.

26. Schaffner and Baird, "Into the Dustbin of History?" 144-51.

27. A book on how to conduct condition surveys and on using handheld devices is being prepared by Brian Baird and will be published by Scarecrow Press in the future.

28. Galina Kislovskaya, Preservation Challenges in a Changing Political Climate: A Report from Russia (Washington, D.C.: The Committee on Preservation and Access, 1996); Jordan, Preservation Activities in Bulgaria.

29. SlavCopy is a cooperative, self-funded preservation program, based at the University of Kansas and implemented by the authors, which has run effectively since 1997 . The program facilitates the acquisition of archival-quality reproductions of embrittled volumes at prices kept low by collaborative preservation and reproduction. These reproductions are bound in book format and replicate the original in all respects. To learn more about this program visit the SlavCopy Web site at: http:/ / www.ku.edu/ slavlib/slavcopy.htm. Also, see, Brian J. Baird and Bradley L. Schaffner, "Extinguishing Slow Fires: Cooperative Preservation Efforts," Racing towards Tomorrow, Proceedings of the Ninth National Conference of the Association of College and Research Libraries April 8-11, 1999, ed. Hugh A. Thompson (Chicago: Association of College and Research Libraries, 1999), 228-33. 